\title{
Repeated bleaching events may result in high tolerance and notable gametogenesis in stony corals: Oculina patagonica as a model
}

\author{
Rachel Armoza-Zvuloni ${ }^{1,2,3, *}$, Roee Segal ${ }^{1}$, Esti Kramarsky-Winter ${ }^{1}$, Yossi Loya ${ }^{1}$ \\ ${ }^{1}$ Department of Zoology, Tel Aviv University, Ramat Aviv, Tel Aviv 69978, Israel \\ ${ }^{2}$ The H. Steinitz Marine Biology Laboratory, Interuniversity Institute for Marine Sciences of Eilat, PO Box 469, Eilat 88103, \\ Israel \\ ${ }^{3}$ National Centre for Mariculture, Israel Oceanographic and Limnological Research Ltd., PO Box 1212, Eilat 88112, Israel
}

\begin{abstract}
Coral bleaching events (BEs) are occurring in coral reefs worldwide and are expected to become annual, triggered by seasonal changes in water temperature. The stony coral Oculina patagonica experiences repeated seasonal BEs along the Israeli Mediterranean coast. It thus constitutes a good model for assessing the potential effects of expected repeated BEs on coral physiology. Previous studies have shown that the overlap between bleaching and reproduction seasons in $O$. patagonica impedes gametogenesis. In the present study, we assessed the effect of bleaching on gametogenesis of populations commonly undergoing repeated seasonal BEs, and compared it with the effect of first and second summer BEs on gametogenesis of a population that has not experienced a summer BE in recent years. Interestingly, we found no differences between bleached and non-bleached colonies in most of the reproductive parameters tested in populations undergoing repeated seasonal BEs. We did find, however, that a population that experienced a summer BE for the first time presented significantly lower reproductive parameters in bleached colonies when compared to non-bleached colonies. Furthermore, in the following year, such bleached colonies showed an improvement in reproductive performance when compared to the previous year. The remarkable differences in gametogenesis between colonies experiencing first summer BE and those experiencing repeated seasonal BEs may be the result of improved utilization of alternative energy sources. This study provides the first evidence for notable gametogenesis in corals undergoing repeated bleaching, and suggests that adjustment processes may increase tolerance levels and may play a role in the ability of corals to overcome the expected repeated BEs.
\end{abstract}

KEY WORDS: Repeated seasonal bleaching · Adjustment · Tolerance $\cdot$ Reproduction · Gametogenesis · Oculina patagonica

Resale or republication not permitted without written consent of the publisher

\section{INTRODUCTION}

Coral bleaching is occurring on coral reefs worldwide and has been found to strongly correlate with episodes of high sea-surface temperature (Loya et al. 2001, Oliver et al. 2009). Because of the expected warming of the ocean, by the year 2050 bleaching events (BEs) are expected to increase in frequency until they become annual in most oceans, triggered by seasonal changes in water temperature (Hoegh-Guldberg 1999, Donner et al. 2005).
Bleaching may be caused by a range of stressors, including thermal stress (Goreau \& Hayes 1994), high UV radiation (Gleason \& Wellington 1993), reduced salinity (Goreau 1964, van Woesik et al. 1995), and bacterial infection (Kushmaro et al. 1997), as well as combinations of different stressors (Brown et al. 1995). The loss of zooxanthellae may restrict nutritional acquisition by the coral host, as the zooxanthellae provide most of the coral's daily energetic requirements via translocation of their photosynthates (Muscatine et al. 1984, Davies 1991). Consequently, bleaching often 
results in reduced tissue lipid and protein content (e.g. Fitt et al. 1993), reduced calcification and growth (e.g. Suzuki et al. 2003), increased susceptibility to disease (e.g. Harvell et al. 1999), and increased mortality (e.g. Glynn 1996, Loya et al. 2001). In addition, bleaching also results in decreased reproductive capacity by interfering with gametogenesis and spawning (reviewed by Coles \& Brown 2003).

Previous studies have shown that in some species a decrease in coral fecundity occurred during bleaching (Szmant \& Gassman 1990, Ward et al. 2000), while in other species such decrease was documented only after the symptoms of bleaching had ended (e.g. Omori et al. 2001). An extreme example of such a case is revealed in the significant reductions in fecundity that were measured 2 yr after a BE, both in the natural population of the stony coral Montastrea annularis (Mendes \& Woodley 2002), and in an experiment in which bleaching was induced in the soft coral Lobophytum compactum (Michalek-Wagner \& Willis 2001). Moreover, the rate and degree of improvement in reproductive performance was found to be affected by bleaching duration and severity. Corals achieved their initial reproductive capabilities faster when the bleaching severity was lower (Michalek-Wagner \& Willis 2001, Mendes \& Woodley 2002) and the duration was shorter (Szmant \& Gassman 1990). Coral reproductive success is an essential factor in coral reef survival since it affects the number of propagules available for the renewal of a reef. The potential impact of bleaching on coral reproduction has serious long-term implications, especially if BE frequencies exceed the frequency at which corals can recover from these events and fecundity remains depressed for long periods (Szmant \& Gassman 1990, Van Veghel \& Bak 1994, Ward 1995).

Nevertheless, some corals are less susceptible to bleaching and are able to survive and recover from BEs (Brown \& Suharsono 1990, Jokiel \& Coles 1990, Marshall \& Baird 2000, Jokiel \& Brown 2004). The susceptibility to bleaching often differs among reef areas, coral individuals, populations, species, and higher taxa (Berkelmans \& Oliver 1999, Loya et al. 2001). For example, Grottoli et al. (2006) showed that the Hawaiian coral Montipora capitata recovered from bleaching by changing its feeding strategy and depending on energy resources (Grottoli et al. 2006). Following that study, Cox (2007) examined various reproductive parameters in $M$. capitata but did not find significant differences between colonies that had experienced a single $\mathrm{BE}$ during the previous year and those that had not.

The stony coral Oculina patagonica undergoes repeated seasonal BEs in most locations along the Mediterranean coast of Israel (Fine \& Loya 2004, Segal 2006). Every summer since 1993, when the water temperature approaches its seasonal peak, ca. $80 \%$ of the colonies undergo bleaching (Kushmaro et al. 1998, Israely et al. 2001, Fine \& Loya 2003). When the water temperature drops, most of the colonies regain their symbiotic algae and recover (Shenkar et al. 2005). O. patagonica is a gonochoric coral, in which female and male gonads appear in May and July (respectively) and reach maturity by late August. Spawning takes place during 2 consecutive full-moon nights in September (Fine et al. 2001). Fine et al. (2001) examined the reproductive capabilities of bleached and non-bleached colonies between 1994 and 1999 and found no gonads in bleached colonies. Thus, they suggested that this overlap of the bleaching and reproductive periods severely impacted reproduction in O. patagonica populations.

Repeated seasonal BEs (i.e. BEs that occur annually, triggered by seasonal changes in water temperature and followed by the recovery of the bleached colonies) are still fairly uncommon in coral reef systems, making their effect on coral reproduction largely unknown. To date, studies that assessed the effect of bleaching on coral reproduction have examined the abilities of corals to recover from a single BE. The fact that Oculina patagonica has been undergoing repeated seasonal BEs for more than a decade (Fine \& Loya 2004) and that these BEs overlap temporally with gametogenesis (Fine et al. 2001) provided us with an opportunity to use this coral as a model for studying the effects of repeated seasonal BEs on coral reproduction. In the present study, we assessed the effect of repeated seasonal BEs on gametogenesis of O. patagonica populations during 3 bleaching seasons (2004 to 2006) and compared it with the effect of first and second summer BEs on gametogenesis of a population that had not experienced a summer BE in recent years.

\section{MATERIALS AND METHODS}

Study sites and sample collection. The study was carried out at 3 sites along $140 \mathrm{~km}$ of the Mediterranean coast of Israel $\left(33^{\circ} 05^{\prime} \mathrm{N}, 35^{\circ} 06^{\prime} \mathrm{E}\right.$ in the north to $31^{\circ} 40^{\prime} \mathrm{N}, 34^{\circ} 32^{\prime} \mathrm{E}$ in the south): Achziv (AC), SdotYam (SY), and Palmahim (PA) (Fig. 1). Surveys for coral bleaching were performed monthly from May 2004 to December 2005 at Sites SY and AC, except for July and August 2004. At Site PA, surveys were conducted 4 times, in September and December 2004 and May and September 2005. Gametogenesis was estimated at the peak of the reproductive season, $3 \mathrm{wk}$ before spawning (full moon of September; see Fine et al. 2001) in 2004, 2005, and 2006. During the surveys of 2004, no bleached colonies were found in Site AC and, thus, only non-bleached colonies were sampled. In addition, in order to present the water temperature seasonality along the Mediterranean coast of Israel 


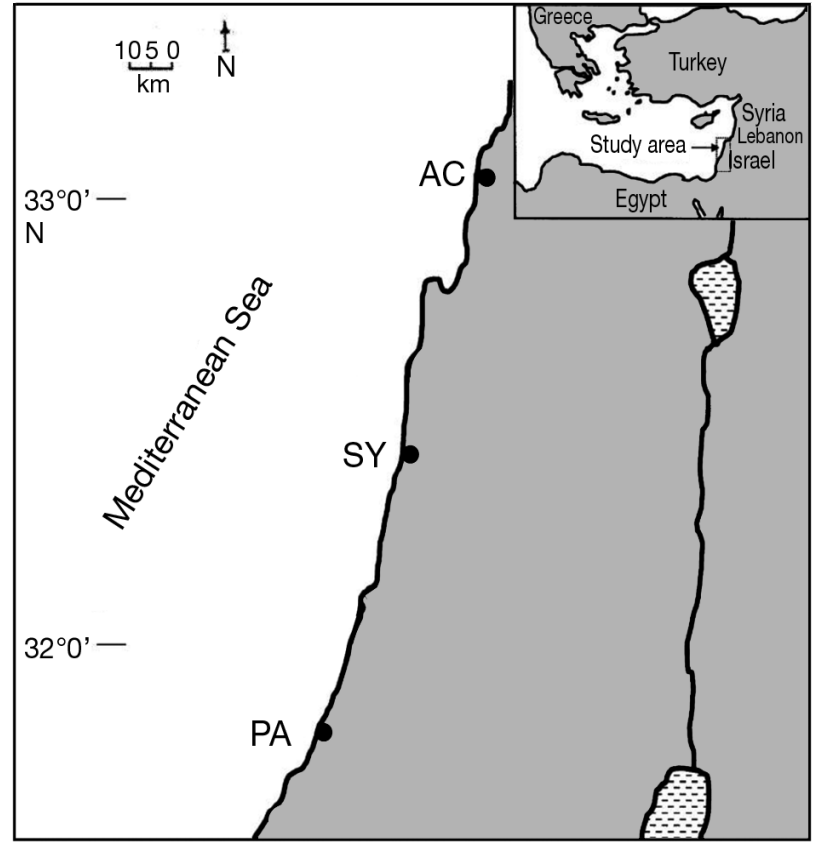

Fig. 1. Study region (inset) and study sites along the Mediterranean coast of Israel. $\mathrm{AC}=$ Achziv, $\mathrm{PA}=$ Palmachim, $\mathrm{SY}=$ Sdot-Yam

and the water temperature amplitude between summer and winter, seawater temperature (presented as monthly means) was measured between May 2004 and December 2005, with $\pm 0.2^{\circ} \mathrm{C}$ accuracy using an Onset Stow Away data-logger placed at Site SY at a depth of $1.5 \mathrm{~m}$ (sampling once every hour).

Bleaching survey. At each site, a defined area of $250 \mathrm{~m}^{2}$ at a depth of 1 to $3 \mathrm{~m}$ was extensively examined using SCUBA. All the colonies (ranging between 40 and 70 individuals) in the area were photographed using a digital camera (Sony DSC P-9). In the laboratory, bleaching severity (i.e. percentage of bleached surface area) of each colony's photograph was measured using the INSPECTOR 2.1 (Matrox Electronic Systems) program. The prevalence (i.e. percentage of bleached colonies) was calculated by counting the number of bleached colonies, then dividing this by the total number of colonies that were observed in the study area. In order to avoid counting colonies that had suffered from physical damage (such as fish bites) as bleached colonies, a colony was scored as 'bleached' only if its bleached surface area was $>5 \%$.

Gametogenesis. Gametogenesis was estimated histologically. Using a corer, 10 bleached and 10 nonbleached colonies were sampled (ca. 10 polyps colony $^{-1}$ ) from each site. A colony was considered 'bleached' or 'non-bleached' only if bleaching severity was $100 \%$ or $0 \%$ (respectively) (Fig. 2); partially bleached colonies were not sampled. The samples were fixed in a solution of $4 \%$ formaldehyde in seawater for $24 \mathrm{~h}$, rinsed in fresh seawater and preserved in $70 \%$ ethanol. Decalcification was carried out using a solution of formic acid and sodium citrate (following Rinkevich \& Loya 1979). Following decalcification, the tissue was rinsed in fresh water and transferred into $70 \%$ ethanol. The tissue was dehydrated in graded ethanol solutions, embedded in paraffin (using a Citadel embedding apparatus), sectioned, and mounted on glass slides. Following deparaffination, the cross-sections were stained with hematoxylin and eosin, and examined under a light microscope.

The number and developmental state of the gonads were assessed in the lower mid-section of each polyp.

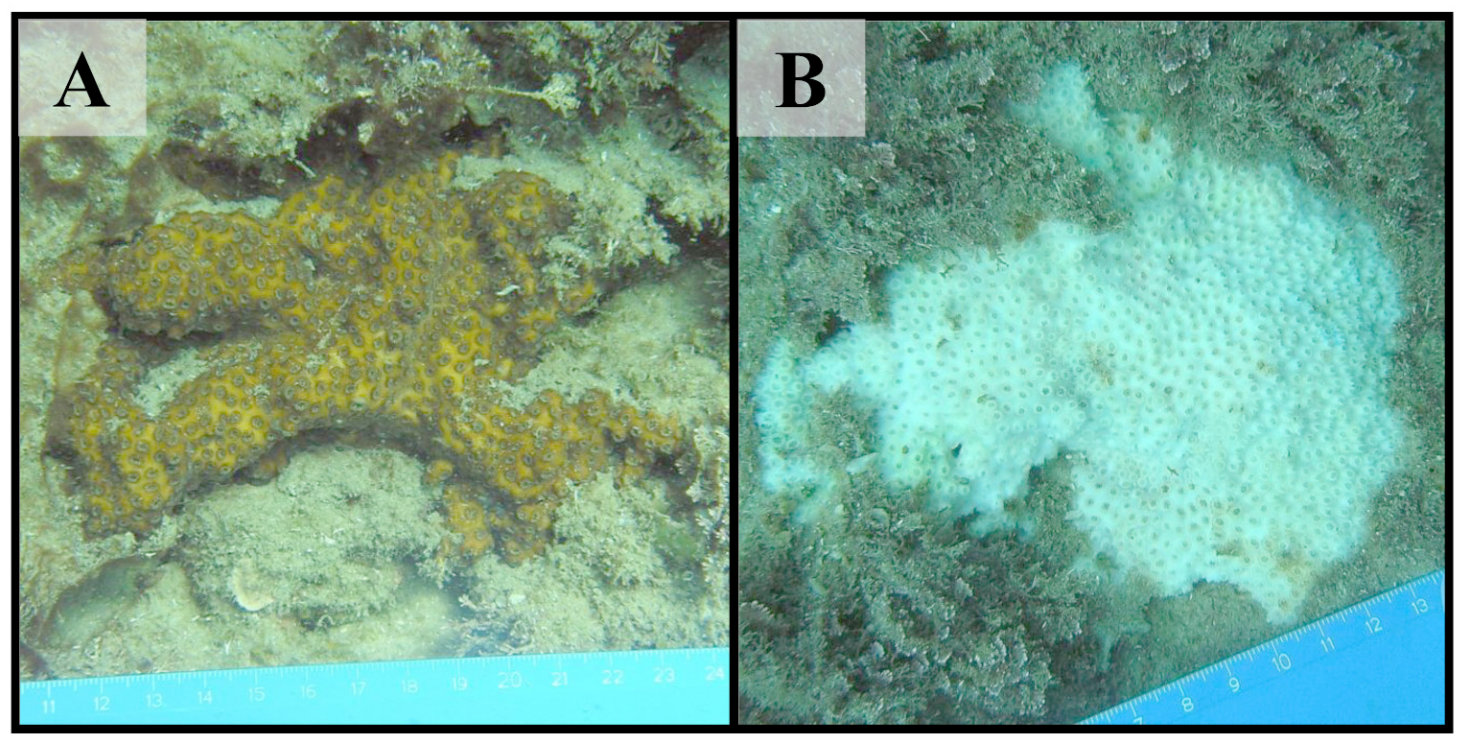

Fig. 2. Oculina patagonica. An encrusting stony coral abundant on the vermetid reef flats and vertical walls of the sandstone reefs off the coast of Israel. (A) Non-bleached colony, and (B) completely bleached colony with intact tissue layer 
In female colonies, the percentage of polyps with gonads (fertile polyps) and the mean number of oocytes per polyp were recorded. In addition, for each sample we assessed the mean diameter of mature oocytes in 3 randomly chosen polyps that contained at least 10 oocytes with a visible germinal vesicle. In male colonies, we assessed the percentage of polyps with gonads (testes), the average number of testes per polyp, and the percentage of developed testes. Testes were defined as developed when the spermatozoa were characterized by developed flagellae and condensed cytoplasm and nuclear chromatin. The number of replicates (see Table 1) was dictated by the sex ratio of female and male colonies in the samples (which varied between $3: 7,4: 6$, and 5:5). In estimating the percentage of polyps with gonads (fertile polyps), the results were presented for female and male colonies together. In addition, because of technical problems in the sections preparation, not all reproductive parameters could be obtained from all the samples.

Statistical analyses. All statistical analyses were carried out using Statistica 8 and SPSS 12.0.1 statistical software. Arcsine transformations were obtained for all parameters collected as percentages. The data were tested for normality (Kolmogorov-Smirnov test) and homogeneity of variances (Levene's test) before comparisons. For parametric data, differences were tested using 1-way and 2-way ANOVA and a Tukey HSD test for unequal sample size was used for post hoc comparisons. For nonparametric data, we used the parallel Mann-Whitney and Kruskal-Wallis tests. Pearson's correlation test was used to determine the strength of the relationships between monthly mean water temperatures (calculated from data measured at Site SY) and bleaching prevalence and severity of the coral population at Site SY. Comparison of bleaching prevalence and severity between Sites SY and PA was estimated using the Mann-Whitney test and paired $t$-test (respectively). Results are presented as mean \pm SE throughout.

\section{RESULTS}

\section{Temporal pattern of bleaching}

At Site SY, a seasonal pattern of bleaching was observed between May 2004 and December 2005. Two BEs were documented over the 20 mo survey (Fig. 3). Bleaching severity was found to be strongly associated with water temperature (Fig. 3A; $\mathrm{R}^{2}=0.844, \mathrm{p}<0.001$ ). However, bleaching prevalence showed a weak association with water temperature (Fig. 3B; $\mathrm{R}^{2}=0.292, \mathrm{p}<0.05$ ). The prevalence increased rapidly as soon as the temperature rose above $25^{\circ} \mathrm{C}$ (from $8.4 \%$ in May to $53.8 \%$ in June 2004, and from $8.7 \%$ in May to $68.8 \%$ in June 2005) and remained high throughout the high water-temperature season, which was also the reproductive season. In both studied seasons, the level of bleaching was lowest around May, with severity $<4 \%$ and prevalence $<9 \%$, and increased rapidly toward the summer months. In 2004, bleaching reached its highest levels in November (41.5\% severity and 76.7\% prevalence), while in 2005 it was highest in August and September $(64.8 \%$ severity and $83.3 \%$ prevalence, respectively). At Site PA, similar levels of bleaching to those found at Site SY were observed. No differences in both bleaching severity (Mann-Whitney test) and bleaching prevalence (paired $t$-test) were found between the sites in September and December 2004 and in May and September 2005 (surveys taken on the same dates at both sites).

In contrast to Sites SY and PA, colonies at Site AC showed a different bleaching pattern: throughout the summer of 2004 (May to October), BE was not observed, with the exception of 3 bleached colonies out of

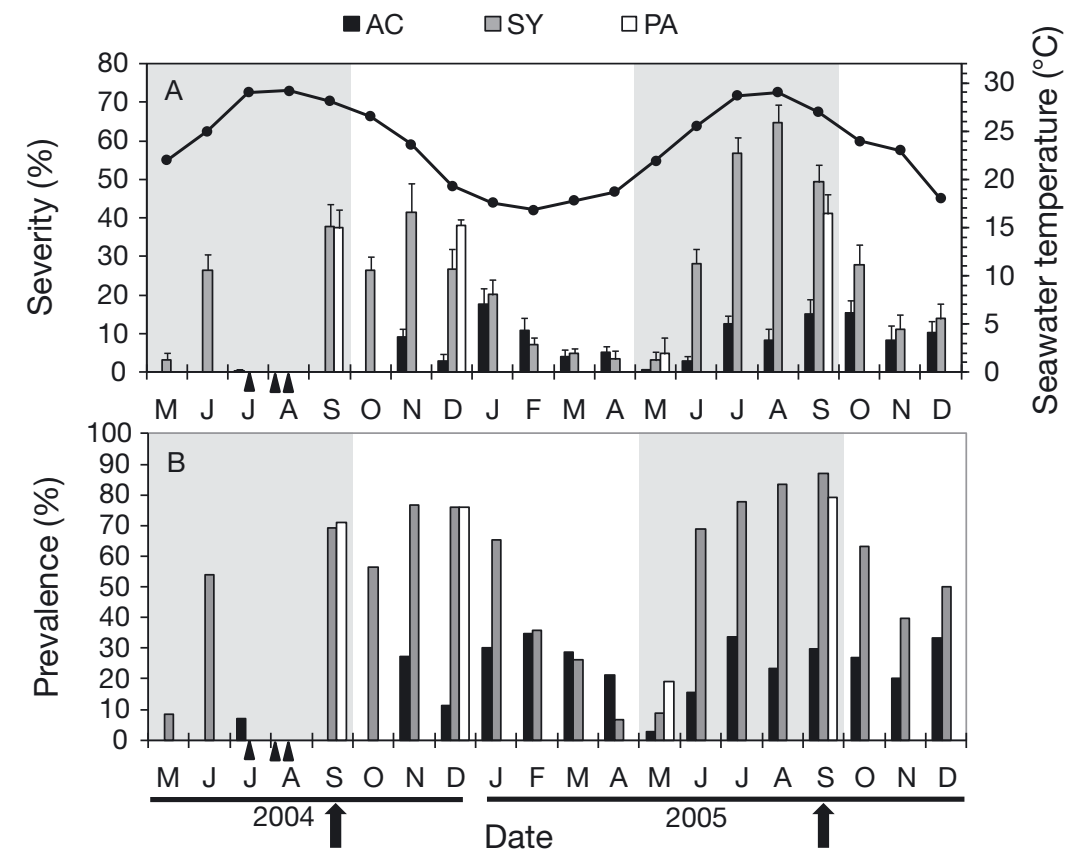

Fig. 3. Oculina patagonica. (A) Bleaching severity (bars; mean \pm SE) and seawater temperature (line with black dots; monthly means of data collected at Site SY demonstrating the seasonality along the East Mediterranean coast and the water temperature amplitude between summer and winter). (B) Bleaching prevalence; 40 to 70 colonies were surveyed monthly for each site. AC = Achziv, PA = Palmachim, SY = Sdot-Yam. Gray area = reproductive season; filled black arrow $=$ spawning; filled black triangle $=$ no data 
$49(6.1 \%)$ that showed very low bleaching severity (ca. $5 \%$ ) during July 2004. Surprisingly, during the winter of 2005 (November to April), a BE occurred at Site $\mathrm{AC}$, with highest levels of $17.5 \%$ bleaching severity in January and $34.7 \%$ bleaching prevalence in February. Since BEs at Site AC had not been observed throughout the $3 \mathrm{yr}$ preceding our study (2001 to 2003; Segal 2006, N. Shenkar pers. comm.), we considered the population at Site $\mathrm{AC}$ as one that had not recently experienced a BE. By the spring of 2005, the bleached Oculina patagonica population at Site AC had recovered, resulting in a seasonal minimum of $0.5 \%$ severity and $2.7 \%$ prevalence in May 2005. Toward the summer months, a summer BE occurred. Bleaching increased concomitantly with the reproductive season, reaching its highest value of $33.6 \%$ prevalence in July and $15.3 \%$ severity in October. Moreover, bleaching severity and prevalence remained relatively high until December 2005 (10.3\% and 33\%, respectively).

\section{Gametogenesis in populations undergoing bleaching}

Examination of the histological crosssections unexpectedly showed that bleached colonies in most cases exhibited notable gametogenesis, similarly to the non-bleached colonies at Sites SY and PA. In most comparisons of reproductive parameters between bleached and non-bleached colonies, we found insignificant differences. Number of oocytes per polyp and mean oocyte diameter did not differ at all between bleached and non-bleached colonies (Table 1; see also histological sections of non-bleached colonies in Fig. 4 versus bleached colonies in Fig. 5A,B). With the other parameters, i.e. percentage of polyps with gonads, number of testes per polyp, and percentage of developed testes, lower values were found in bleached colonies in only 5 out of 15 comparisons (ca. 33\%; Table 1). In these 5 comparisons, even though bleached colonies showed significantly lower levels than non-bleached colonies, they still demonstrated a notable level of reproductive activity (e.g. percentage polyps with gonads at Site PA was $73 \pm 10 \%$ in bleached versus $97 \pm 3 \%$ in non-bleached colonies in 2004).

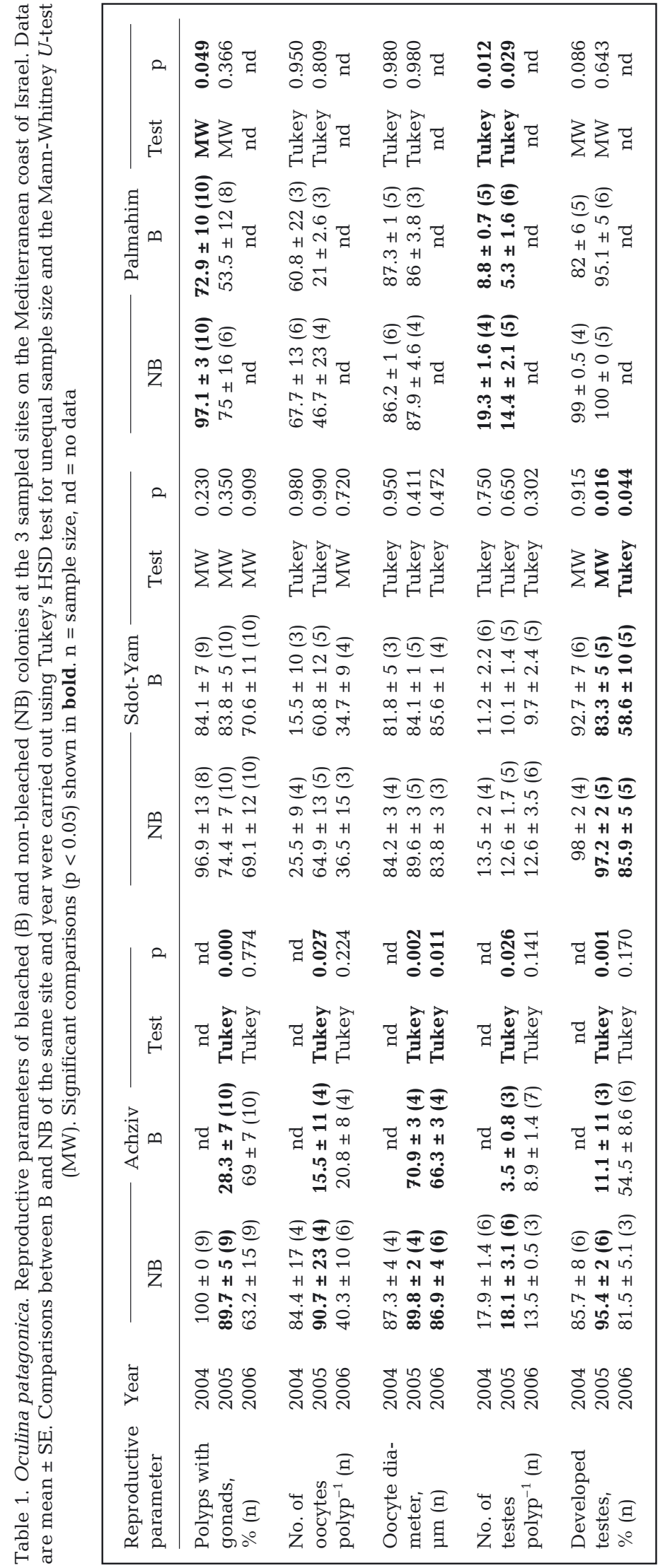




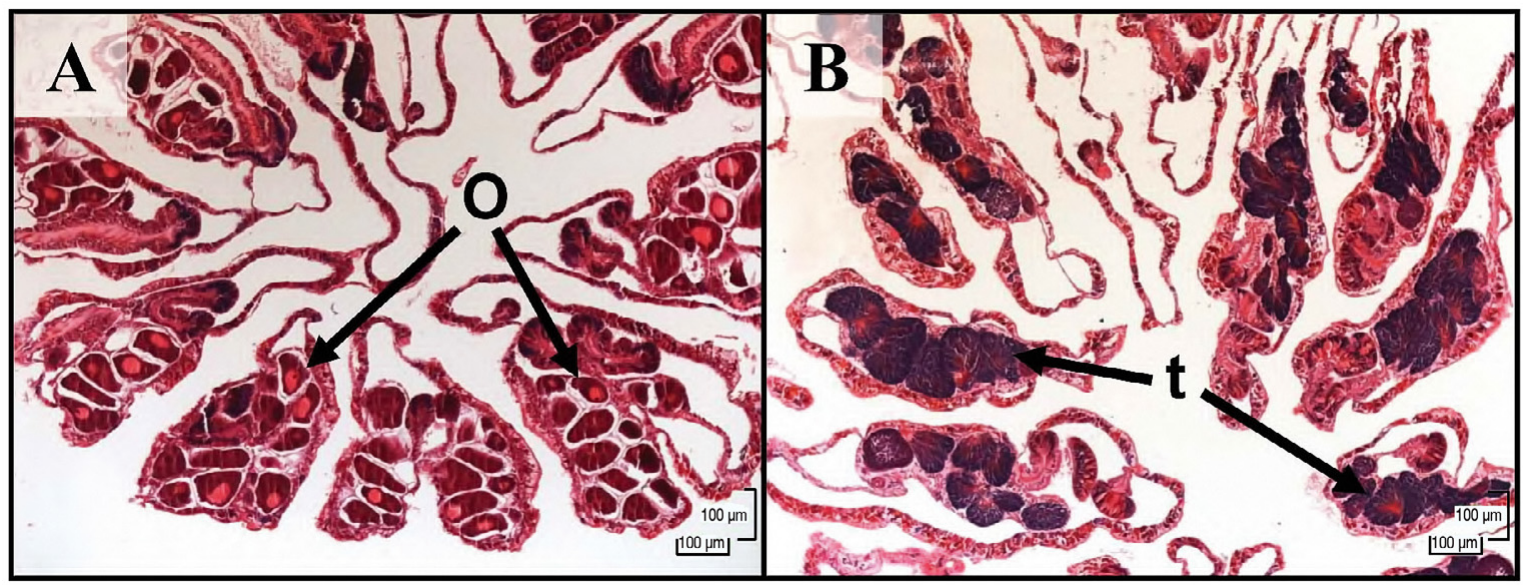

Fig. 4. Oculina patagonica. Non-bleached colony cross-sections. (A) A female with mature oocytes (o) within mesenteries, and (B) a male with developed testes (t) (i.e. mature spermatozoa) within mesenteries

In contrast to Sites SY and PA, in September 2004, bleached colonies were not observed at Site AC, and thus only non-bleached colonies were sampled and analyzed. During the survey of 2005, totally bleached colonies were found at Site AC for the first time. This provided us with an opportunity to examine reproductive parameters in a population that had experienced its first summer BE (following at least 4 yr without summer bleaching between 2001 and 2004). Bleached colonies from Site AC sampled in 2005 demonstrated significantly lower values of reproductive parameters than nonbleached colonies $(\mathrm{p}<0.05$ for all tested parameters; Table 1). Their gonads were poorly developed compared to non-bleached colonies (i.e. smaller oocytes and lower percentage of developed testes), the percentage of polyps with gonads was lower, and each polyp contained fewer oocytes and testes (Table 1, Fig. 5C,D). Comparisons between bleached colonies from Site AC and bleached colonies from Sites SY and PA (the 2 populations undergoing repeated seasonal BEs) sampled in 2005 showed that at Site AC, coral gonads were significantly less developed; their oocytes were smaller in diameter $(p=0.005$ and $p=0.017$ compared to Sites SY and PA, respectively); and the percentage of developed testes was lower $(p=0.005$ and $p=0.001$, respectively). In addition, the percentage of polyps with gonads in bleached colonies from Site AC was significantly lower than those from Site SY $(p=0.0002)$.

During the summer of 2006, the population at Site AC bleached again. Bleached and non-bleached colonies were sampled and their reproductive parameters were examined. We found that reproductive performance had improved in bleached colonies from Site AC when compared with the previous year (e.g. Fig. 5E,F). Whereas in 2005 all reproductive parame- ters of the bleached colonies from Site AC were lower compared to non-bleached colonies, in 2006 only the mean oocyte diameter was lower $(66.3 \pm 3 \mu \mathrm{m}$ in bleached versus $86.9 \pm 4 \mu \mathrm{m}$ in non-bleached colonies, $\mathrm{p}=0.011$; Table 1). This parameter was also the only parameter that was found to be lower in bleached colonies from Site AC compared to bleached colonies from Site SY in 2006 ( $p=0.01$ ). Furthermore, comparisons of reproductive parameters of bleached colonies at Site AC from 2005 and 2006 show that, following the bleaching in 2006, the percentage of polyps with gonads was higher $(p=0.001)$, as was the percentage of developed testes $(p=0.02$; Table 1$)$.

\section{DISCUSSION}

\section{Temporal pattern of bleaching and population resistance and tolerance}

The seasonal patterns of bleaching found at Sites SY and PA correspond with previous studies that reported that most populations of Oculina patagonica along the Israeli coast commonly undergo repeated seasonal BEs. This similarity is evident in the duration of the bleaching episodes (June until March), their maximal severity (ca. 40 to $65 \%$ ), and prevalence (ca. $80 \%$; Kushmaro et al. 1998, Israely et al. 2001, Fine \& Loya 2003, Shenkar et al. 2005, Segal 2006). Despite the repeated BEs, which have been documented since 1993 (Fine \& Loya 2004), these populations are known to survive and recover. Moreover, it was found that the colonies regain their pre-bleaching zooxanthella density during the winter and prior to the following $\mathrm{BE}$ (Shenkar et al. 2006). At Site AC, a different temporal 
Female

Male

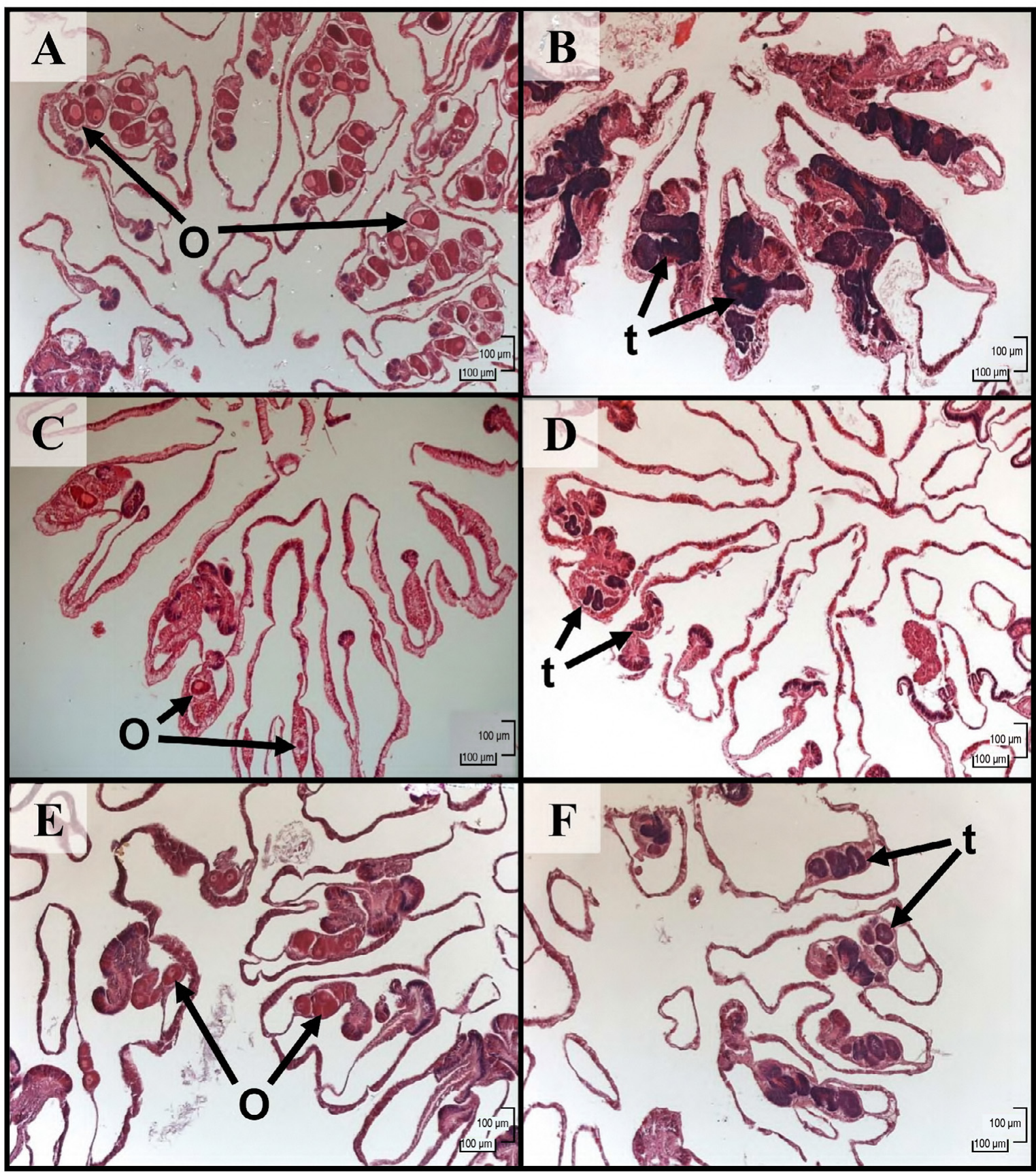

Fig. 5. Oculina patagonica. Bleached colony cross-sections. (A,B) Well-developed and packed gonads in polyps from colonies collected in 2005 at Sdot-Yam; (C,D) few and undeveloped gonads in colonies collected in 2005 at Achziv, after experiencing their first summer bleaching event; (E,F) small oocytes and testes in corals collected in 2006 at Achziv, from colonies experiencing a second summer bleaching event. $\mathrm{o}=$ oocyte, $\mathrm{t}=$ testis

pattern of bleaching was documented. Although water temperature was high at this site, a BE was not observed throughout the summers of 2001, 2002 (N. Shenkar pers. comm.), 2003 (Segal 2006), and 2004
(Fig. 3). Surprisingly, during the winter of 2004-2005 (November to March), a BE occurred at Site AC. Since bleaching may be caused by a range of stressors (e.g. reduced salinity: van Woesik et al. 1995; low tempera- 
ture: Coles \& Fadlallah 1991), it is most likely that an environmental stressor other than elevated temperature was responsible for this BE. However, the cause of this winter BE is unknown. Following this anomalous winter $\mathrm{BE}$, the population at Site AC experienced 2 consecutive summer BEs concomitantly with the reproductive seasons in the summers of 2005 and 2006.

The level of coral susceptibility to bleaching can be defined according to 2 useful terms: 'resistance' and 'tolerance'. Corals with low resistance are those that show a high predilection to bleach under a given thermal stress; corals with high tolerance to bleaching are those that show low mortality percentages under the same stress (Obura 2005). Following these concepts, Oculina patagonica populations from Sites SY and PA have low resistance to bleaching, as they commonly undergo repeated seasonal BEs, but show high tolerance to bleaching since they also recover. Indeed, colonies from these sites have not only survived repeated BEs, but have also managed to successfully undergo a highly energetically costly process: gametogenesis.

\section{Gametogenesis and adjustment to bleaching}

We found that colonies of Oculina patagonica from Sites SY and PA that commonly undergo repeated seasonal BEs contained, in most cases, well-developed gonads throughout the 3 consecutive reproduction seasons (2004 to 2006; Table 1, Fig. 5A,B). These findings contradict those of a number of previous studies, which emphasized the detrimental impact of bleaching on coral reproduction in various coral species, including Montastrea annularis (Szmant \& Gassman 1990, Mendes \& Woodley 2002), Acropora sp. (Omori et al. 2001), Lobophytum compactum (Michalek-Wagner \& Willis 2001), and O. patagonica (Lubinevsky 2000, Fine et al. 2001). Specifically, in O. patagonica, Fine et al. (2001) reported that no gonads were found in bleached colonies sampled from a variety of sites (including SY) during 5 reproductive seasons between 1994 and 1999.

The dramatic differences found in the reproductive efforts of bleached colonies from SY and PA between 1994 and 1999 (Fine et al. 2001) and 2004 to 2006 (present study) may be the expression of physiological adjustment to bleaching. Colonies commonly undergoing repeated BEs may have become adjusted to the reduced supply of photoassimilates from their symbiotic algae and hence developed greater tolerance. Consequently, they may exploit alternative energy sources during the bleaching period. These findings suggest that adjustment processes acting during short temporal windows may actually constitute useful mechanisms for overcoming the expected repeated seasonal BEs.
It is important to note that during the period 1994 to 1999, the bleached colonies suffered additive effects, including both nutritional restriction (due to bleaching; Fine et al. 2002, Fine \& Loya 2003) and bacterial infection (by Vibrio shiloi, the causative agent of bleaching; Kushmaro et al. 1998, Ben-Haim et al. 1999), which may have directly affected gametogenesis. Since 2004, $V$. shiloi has no longer been detected in bleached Oculina patagonica colonies (Reshef et al. 2006). Although there is no evidence for a direct effect of the bacterium on the coral's reproductive development, the disappearance of $V$. shiloi may have played a role in the adjustment process leading to successful gametogenesis.

Unlike colonies from Sites SY and PA that commonly undergo repeated seasonal BEs, colonies from Site AC experienced their first summer BE in 2005 (after at least 4 yr without summer bleaching) and concurrently showed reduced reproductive effort. The most likely explanation for the considerable decrease in fecundity of these colonies may be that of physiological stress and a reduction in the coral's energetic reservoirs, as has been reported to occur in other corals (Szmant \& Gassman 1990, Michalek-Wagner \& Willis 2001, Mendes \& Woodley 2002). As indicated, since 2004 the bacterium Vibrio shiloi has no longer been detected in these corals and therefore could not be the cause of the observed reproductive failure. Surprisingly, in 2006, following another summer BE, bleached colonies from Site AC showed improved reproductive parameters in comparison to the previous year. This improvement between 2005 and 2006 summer BEs (Table 1) may indicate that, in comparison to what had occurred with the SY and PA populations between 1999 and 2004, the AC population had adjusted to beaching more quickly.

\section{Suggestions for alternative energy resources}

Corals may be capable of acclimatization and selective adaptation to elevated temperatures that may result in bleaching-resistant coral populations (see review by Coles \& Brown 2003). In the case of Oculina patagonica, adjustment of bleached colonies to bleaching most probably involves the exploitation of alternative energy resources in order to supply the coral with enough energy for gonadal development. There are several possible mechanisms that may explain the observed changes in reproductive capabilities of bleached colonies:

(1) Bleached Oculina patagonica colonies may rely on their winter energy reservoirs for their summer energetic demand. Shenkar et al. (2006) found that during the winter, O. patagonica had comparatively 
high algal densities that reached a maximum of $8.8 \times$ $10^{6} \pm 1.8 \times 10^{6}$ cells $\mathrm{cm}^{2}$. It is possible that the corals can store some portion of the zooxanthellae photoassimilates during the winter and use them during the summer for gonadal development. In addition, since growth is greatly reduced during the summer (Shenkar et al. 2005), the available energy may be utilized instead for reproductive activities.

(2) An additional possibility is that the coral tissue itself and its symbiotic algae may provide extra energetic input via catabolic processes. Reduced biomass of bleached colonies compared with non-bleached colonies (50\% less tissue per surface area; data not shown) may indicate that the colonies catabolize their tissue in order to maintain metabolic activities such as gametogenesis (Szmant \& Gassman 1990, Mendes \& Woodley 2002). Indeed, Downs et al. (2009) showed that corals digest their zooxanthellae via the autophagic pathway, a pathway known to recycle cellular components during periods of high irradiance and temperature.

(3) Endolithic algae reported in Oculina patagonica skeleton and in contact with the coral tissues may act as an additional external, alternative source of energy (Fine \& Loya 2002). These endolithic algae receive increased photosynthetically active radiation during BEs, when the coral tissue is transparent. Thus, during these periods, the endolithic algae may produce more photoassimilates, which are translocated to the corals. Fine \& Loya (2002) suggested that this source of energy is insufficient for gametogenesis in the host coral, since no gonads were found in bleached colonies during the period 1994 to 1999 (Fine et al. 2001). However, it is possible that the ability of the corals to utilize the photoassimilates derived from the endolithic community may have been improved in subsequent years, thus allowing gonad development.

(4) The corals may have changed their feeding strategy and relied more on an external source of heterotrophic carbon. It has been shown that heterotrophic carbon can become a significant energy source for corals when photosynthetic carbon is unavailable, as occurs during BEs, in deep and/or turbid waters (Anthony 2000, Palardy et al. 2005, Houlbrèque \& Ferrier-Pagès 2009). An example of this is the Hawaiian coral Montipora capitata, which recovers from bleaching by changing its feeding strategy. Grottoli et al. (2006) showed that when zooplankton are available, bleached $M$. capitata colonies may acquire large quantities of heterotrophic carbon (more than 5-fold higher than non-bleached colonies) and are thus not dependent on photoassimilates in order to recover energy reserves. We consider this as the most likely mechanism, since Oculina patagonica is a facultative symbiotic species capable of heterotrophic feeding (there are abundant azooxanthellate colonies of $O$. patagonica that inhabit dark caves; Lubinevsky 2000), and a large amount of energy required for gametogenesis can be acquired in this way.

It is also possible that no one mechanism is involved but that a combination of these processes occurs.

\section{Oculina patagonica: an exclusive case study or a predictor}

Oculina patagonica is known to grow under highly variable conditions. It inhabits shallow pools where the temperature can reach $41{ }^{\circ} \mathrm{C}$ and salinity can fluctuate between 28 and 50\% (Rosenberg \& Falkovitz 2004). Similarly to O. patagonica, other coral species that were found inhabiting extreme environments exhibit high resistance and/or high tolerance to bleaching (e.g. high seawater temperatures; Gardiner 1903, Vaughan 1914, Orr \& Moorhouse 1933, Motoda 1940, Meesters \& Bak 1993, Tomascik et al. 1997). For example, Kinsman (1964) found massive nonbleached colonies of Porites sp. in water temperature of $>40^{\circ} \mathrm{C}$ in the Arabian Gulf, and Craig et al. (2001) found 52 coral species that survived maximum daily temperatures of $34.5^{\circ} \mathrm{C}$ for $35 \mathrm{~d}$ with virtually no bleaching. There is increasing evidence that O. patagonica is not an exclusive case. For example, there is evidence for resistance and recovery from bleaching through acclimatization processes in a variety of corals that experienced stress conditions, such as solar bleaching in Goniastrea aspera (Brown et al. 2000, 2002) and thermal stress in Montipora verrucosa (Coles \& Jokiel 1978). In contrast, HoeghGuldberg (1999) noted that most information suggests that the capacity for acclimatization by corals has already been reached, and that future adaptation will be too slow to prevent the predicted decline in coral reef populations.

Our findings suggest that coral species with a high tolerance to bleaching may overcome some energetic barriers to reproduction and complete gametogenesis during periods of repeated seasonal BEs. These species could become the dominant coral species on reefs and may help to prevent the loss of coral cover and phase shifts from a coral to an algae-dominated community.

Acknowledgements. This work was supported by the Israel Science Foundation and the Raynor Chair for Environmental Conservation Research (to Y.L.). We thank A. Zvuloni for his advice and for reviewing the manuscript, I. Brickner and B. Colorni for histological sectioning, N. Shenkar for her help in selecting the studied sites, I. Mizrahi and D. Sharon for their assistance with fieldwork, and N. Paz for her editorial assistance. 


\section{LITERATURE CITED}

Anthony KRN (2000) Enhanced particle-feeding capacity of corals. Coral Reefs 19:59-67

Ben-Haim Y, Banin E, Kushmaro A, Loya Y, Rosenberg E (1999) Inhibition of photosynthesis and bleaching of zooxanthellae by the coral pathogen Vibrio shiloi. Environ Microbiol 1:223-229

Berkelmans R, Oliver JK (1999) Large-scale bleaching of corals on the Great Barrier Reef. Coral Reefs 18:55-60

Brown BE, Suharsono (1990) Damage and recovery of coral reefs affected by El Niño related seawater warming in the Thousand Islands, Indonesia. Coral Reefs 8:163-170

> Brown BE, Le Tissier MDA, Bythell JC (1995) Mechanisms of bleaching deduced from histological studies of reef corals sampled during a natural bleaching event. Mar Biol 122: 655-663

Brown BE, Dunne RP, Goodson MS, Douglas AE (2000) Bleaching patterns in reef corals. Nature 404:142-143

Brown BE, Downs CA, Dunne RP, Gibb SW (2002) Exploring the basis of thermotolerance in the reef coral Goniastrea aspera. Mar Ecol Prog Ser 242:119-129

- Coles SL, Brown BE (2003) Coral bleaching - capacity for acclimatization and adaptation. Adv Mar Biol 46:183-223

- Coles SL, Fadlallah YH (1991) Reef coral survival and mortality at low temperatures in the Arabian Gulf: new speciesspecific lower temperature limits. Coral Reefs 9:231-237

> Coles SL, Jokiel PL (1978) Synergistic effects of temperature, salinity and light on the hermatypic coral Montipora verrucosa. Mar Biol 49:187-195

$>$ Cox EF (2007) Continuation of sexual reproduction in Montipora capitata following bleaching. Coral Reefs 26:721-724

Craig P, Birkeland C, Belliveau S (2001) High temperatures tolerated by a diverse assemblage of shallow-water corals in American Samoa. Coral Reefs 20:185-189

Davies PS (1991) Effect of daylight variations on the energy budgets of shallow-water corals. Mar Biol 108:137-144

> Donner SD, Skirving WJ, Little CM, Oppenheimer M, HoeghGuldberg O (2005) Global assessment of coral bleaching and required rates of adaptation under climate change. Glob Change Biol 11:2251-2265

Downs CA, Kramarsky-Winter E, Martinez J, Kushmaro A, Woodley CM, Loya Y, Ostrander GK (2009) Symbiophagy as a cellular mechanism for coral bleaching. Autophagy 5:211-216

Fine M, Loya Y (2002) Endolithic algae: an alternative source of photoassimilates during coral bleaching. Proc Biol Sci 269:1205-1210

Fine M, Loya Y (2003) Alternate coral-bryozoan competitive superiority during coral bleaching. Mar Biol 142:989-996

Fine M, Loya Y (2004) Coral bleaching in a temperate sea: from colony physiology to population ecology. In: Rosenberg E, Loya Y (eds) Coral health and disease. SpringerVerlag, Berlin, p 143-155

- Fine M, Zibrowius H, Loya Y (2001) Oculina patagonica: a non-lessepsian scleractinian coral invading the Mediterranean Sea. Mar Biol 138:1195-1203

Fine M, Oren U, Loya Y (2002) Bleaching effect on regeneration and resource translocation in the coral Oculina patagonica. Mar Ecol Prog Ser 234:119-125

Fitt WK, Spero HJ, Halas J, White MW, Porter JW (1993) Recovery of the coral Montastrea annularis in the Florida Keys after the 1987 Caribbean 'bleaching event'. Coral Reefs 12:57-64

Gardiner JS (1903) The fauna and geography of the Maldive and Laccadive archipelagoes. Cambridge University Press, Cambridge
Gleason DF, Wellington GM (1993) Ultraviolet radiation and coral bleaching. Nature 365:836-838

Glynn PW (1996) Coral reef bleaching: facts, hypotheses, and implications. Glob Change Biol 2:495-509

Goreau TF (1964) Mass expulsion of zooxanthellae from Jamaican reef communities after hurricane Flora. Science 145:383-386

Goreau TJ, Hayes RL (1994) Coral bleaching and ocean 'hot spots'. Ambio 23:176-180

Grottoli AG, Rodrigues LJ, Palardy JE (2006) Heterotrophic plasticity and resilience in bleached corals. Nature 440: 1186-1189

> Harvell CD, Kim K, Burkholder JM, Colwell RR and others (1999) Emerging marine diseases-climate links and anthropogenic factors. Science 285:1505-1510

$>$ Hoegh-Guldberg O (1999) Climate change, coral bleaching and the future of the world's coral reefs. Mar Freshw Res 50:839-866

Houlbrèque F, Ferrier-Pagès C (2009) Heterotrophy in tropical scleractinian corals. Biol Rev 84:1-17

Israely T, Banin E, Rosenberg E (2001) Growth, differentiation and death of Vibrio shiloi in coral tissue as a function of seawater temperature. Aquat Microb Ecol 24:1-8

Jokiel PL, Brown EK (2004) Global warming, regional trends and inshore environmental conditions influence coral bleaching in Hawaii. Glob Change Biol 10:1627-1641

Jokiel PL, Coles SL (1990) Response of Hawaiian and other Indo-Pacific reef corals to elevated temperature. Coral Reefs 8:155-162

Kinsman DJJ (1964) Reef coral tolerance of high temperatures and salinities. Nature 202:1280-1282

Kushmaro A, Rosenberg E, Fine M, Loya Y (1997) Bleaching of the coral Oculina patagonica by Vibrio AK-1. Mar Ecol Prog Ser 147:159-165

Kushmaro A, Rosenberg E, Fine M, Ben Haim Y, Loya Y (1998) Effect of temperature on bleaching of the coral Oculina patagonica by Vibrio AK-1. Mar Ecol Prog Ser 171:131-137

- Loya Y, Sakai K, Yamazato K, Nakano Y, Sambali H, van Woesik R (2001) Coral bleaching: the winners and the losers. Ecol Lett 4:122-131

Lubinevsky H (2000) Light and shade adapted Mediterranean corals. MS dissertation, Tel-Aviv University

Marshall PA, Baird AH (2000) Bleaching of corals on the Great Barrier Reef: differential susceptibilities among taxa. Coral Reefs 19:155-163

Meesters EH, Bak RPM (1993) Effects of coral bleaching on tissue regeneration potential and colony survival. Mar Ecol Prog Ser 96:189-198

- Mendes JM, Woodley JD (2002) Effect of the 1995-1996 bleaching event on polyp tissue depth, growth, reproduction and skeletal band formation in Montastraea annularis. Mar Ecol Prog Ser 235:93-102

> Michalek-Wagner K, Willis BL (2001) Impacts of bleaching on the soft coral Lobophytum compactum. I. Fecundity, fertilization and offspring viability. Coral Reefs 19:231-239

Motoda S (1940) The environment and the life of massive reef coral, Goniastrea aspera Verrill, inhabiting the reef flat in Palao. Palao Trop Biol Stn Stud 2:61-104

Muscatine L, Falkowski P, Porter J, Dubinsky Z (1984) Fate of photosynthetic fixed carbon in light- and shade-adapted colonies of the symbiotic coral Stylophora pistillata. Proc R Soc Lond B 222:181-202

- Obura D (2005) Resilience and climate change: lessons from coral reefs and bleaching in the Western Indian Ocean. Estuar Coast Shelf Sci 63:353-372

Oliver JK, Berkelmans R, Eakin CM (2009) Coral bleaching in 
space and time. In: van Oppen MJH, Lough JM (eds) Coral bleaching. Springer-Verlag, Berlin, p 21-39

Omori M, Fukami H, Kobinata K, Hatta M (2001) Significant drop of fertilization of Acropora corals in 1999: an aftereffect of heavy coral bleaching? Limnol Oceanogr 46: 704-706

Orr AP, Moorhouse FW (1933) Variations in some physical and chemical conditions on and near Low Isles Reef. British Museum Greta Barrier Reef Expedition 1928-1929, Sci Rep 2. 4:87-98

Palardy JE, Grottoli AG, Matthews KA (2005) Effects of upwelling, depth, morphology and polyp size on feeding in three species of Panamkanian corals. Mar Ecol Prog Ser 300:79-89

Reshef L, Koren O, Loya Y, Zilber-Rosenberg I, Rosenberg E (2006) The coral probiotic hypothesis. Environ Microbiol 8:2068-2073

Rinkevich B, Loya Y (1979) The reproduction of the Red Sea coral Stylophora pistillata. I. Gonads and planulae. Mar Ecol Prog Ser 1:133-144

Rosenberg E, Falkovitz L (2004) the Vibrio shiloi/Oculina patagonica model system of coral bleaching. Annu Rev Microbiol 58:143-159

Segal R (2006) Bleaching of the coral Oculina patagonica: ecological, physiological and genetic aspects of different populations along the coast of Israel. MS dissertation, TelAviv University

Shenkar N, Fine M, Loya Y (2005) Size matters: bleaching dynamics of the coral Oculina patagonica. Mar Ecol Prog

Editorial responsibility: Charles Birkeland, Honolulu, Hawaii, USA
Ser 294:181-188

> Shenkar N, Fine M, Kramarsky-Winter E, Loya Y (2006) Population dynamics of zooxanthellae during a bacterial bleaching. Coral Reefs 25:223-227

- Suzuki A, Gagan MK, Fabricius KE, Isdale PJ, Yukino I, Kawahata H (2003) Skeletal isotope microprofiles of growth perturbations in Porites corals during the 19971998 mass bleaching event. Coral Reefs 22:357-369

Szmant AM, Gassman NJ (1990) The effects of prolonged bleaching on the tissue biomass and reproduction of the reef coral Montastrea annularis. Coral Reefs 8:217-224

Tomascik T, Mah AJ, Nontji A, Moosa MK (1997) The ecology of the Indonesian seas. Periplus, Hong Kong

- Van Veghel MLJ, Bak RPM (1994) Reproductive characteristics of the polymorphic Caribbean reef building coral Montastrea annularis. III. Reproduction in damaged and regenerating colonies. Mar Ecol Prog Ser 109:229-233

Van Woesik R, De Vantier LM, Glazebrook JS (1995) Effects of Cyclone Joy on nearshore coral communities of the Great Barrier Reef. Mar Ecol Prog Ser 128:261-270

Vaughan TW (1914) Reef corals of the Bahamas and of Southern Florida. Carnegie Inst Wash Year Book 13:222-226

$>$ Ward S (1995) The effect of damage on the growth, reproduction and storage of lipids in the scleractinian coral Pocillopora damicornis. J Exp Mar Biol Ecol 187:193-206

Ward S, Harrison P, Hoegh-Guldberg O (2000) Coral bleaching reduces reproduction of scleractinian corals and increases their susceptibility to future stress. Proc 9th Int Coral Reef Symp, Bali 2:1123-1128

Submitted: April 19, 2010; Accepted: January 1, 2011 Proofs received from author(s): March 16, 2011 